\title{
Knowledge and Use of Birth Control Methods for Family Planning by Married People in Nsukka Education Zone of Enugu State
}

\author{
Chinenye Ifeoma Ogidi ${ }^{1}$, Anthony U. Okere ${ }^{1}$, Shulamite E. Ogbuabor ${ }^{1}$, Angela Ngozi Nwadike ${ }^{1}$, \\ Stella Anietie Usen ${ }^{2}$, Amobi Julia Onumonu ${ }^{1}$, Lilian Chijioke Ozoemena ${ }^{1}$, \\ Nkechinyere Charity Edeh ${ }^{3} \&$ Chisom E. Egwim ${ }^{1}$ \\ ${ }^{1}$ Department of Educational Foundations, University of Nigeria, Nsukka, Enugu State, Nigeria \\ ${ }^{2}$ Department of Educational Foundations (Guidance and Counselling Unit), College of Education, AfahaNsit, \\ Akwa Ibom State, Nigeira \\ ${ }^{3}$ Department of Social Science Education, University of Nigeria, Nsukka, Enugu State, Nigeria \\ Correspondence: Shulamite E. Ogbuabor, Department of Educational Foundations, University of Nigeria, Nsukka, \\ Enugu State, Nigeria. E-mail: shulamite.ogbuabor@unn.edu.ng
}

Received: May 12, 2019 Accepted: June 15, 2019 Online Published: July 25, 2019

doi:10.5539/gjhs.v11n8p96 URL: https://doi.org/10.5539/gjhs.v11n8p96

\begin{abstract}
Objective: The study investigated the knowledge level and use of birth control methods by married people for family planning in Nsukka Education Zone of Enugu state.

Materials and Methods: The population of this study comprised 4450 married people who registered for marriage from 2010 to 2017 in Nsukka Education Zone of Enugu State. The sample was 445 respondents (210 married males and 235 married females). The instrument for data collection was a questionnaire titled: Knowledge and use of birth control methods for family planning questionnaire (KUBCM). The study was guided by four research questions and four hypotheses. The (KUBCM) research questions were answered using mean and standard deviation while t-test statistics was used to test the hypotheses at 0.05 level of significance.

Results: The results obtained showed that married people in Nsukka Education zone have knowledge of birth control methods; that they make use of birth control methods to a great extent; and that there is a significant difference in the mean responses of male and female married people on the extent to which married people make use of birth control methods for family planning.

Conclusion: Both male and female married people have knowledge of common birth control methods of family planning, therefore, couples should discuss together which birth control method of family planning they want to adopt. It should not be a one-man affair. We recommend among others, the full integration of the male population in the family planning programmes, and provision of sensitization programmes aimed at improving male involvement in family planning by government and non-governmental
\end{abstract}

Keywords: birth control methods, family planning, knowledge, married people, use

\section{Introduction}

Since the creation of man, marriage has existed. Marriage is the union of a man and a woman making them husband and wife, love being a powerful tie. It was made for help, procreation and companionship (Agbe, 1998). Marriage is a culturally accepted and sexual union between couples. It involves reciprocal right and obligations between spouses and their future children (Onyima, 2014). Marriage is the joining of two persons in love with the approval of parents, witnesses and guardians for the sake of companionship and procreation (Burk, 2000). People marry for one or many reasons including the desire for economic or emotional security, a home and children, companionship, protection and social position. Apart from specific reasons for marrying, the society is organized in such a way that people are expected to marry and give birth (Agbe, 1998). In Nigeria for instance, the rate of births is greater than global averages (Nwachukwu \& Obasi, 2008). This can be traced to the fact that; contraceptive prevalence rate (CPR) is still minimal in Nigeria. Reports according to the International Women Health Coalition, the CPR among women of $15-49$ years age bracket was $8 \%$ for modern measures and $12 \%$ for all measures of controlling birth. Similarly, reports according to studies have shown almost the same minimal rate of adoption of Modern Birth Control Methods (MBCM) (Coleman, 1992; Olugbenga-Bello, Abodunrin, \& Adeomi, 
2011; Ogbe \& Okezie, 2010; Tahir, 2019). Thus, adequate measures need to be taken to control birth in order to prevent over-crowded environment.

Birth control is both traditional means and modern ways of bearing the number of children one desired (Hofman, P. L. et al., 2004). On the other hand, Melissa (2017) sees birth control as the method of regulating and taking control of the number of birth couples wanted in their marital life without producing like fowl. Williams (2012) defined birth control as limitation of child-bearing through a modern means called contraception. In the view of Reynolds et al. 2017, birth control is the volitional limiting of human multiplication, employing such measures as contraception, sexual abstinence, surgical sterilization and induced abortion. It encompasses the number of children in a family as well as the spacing. The author went on to state that birth control includes the array of irrational and rational measures that have been adopted in the endeavour to regulate fecundity and also the replies of groups and of individuals within society to the choice offered by such methods. Bryan, Christine, Barbara and William (2005) view birth control as any way of forestalling birth from occurring. Birth control as a working definition in this present study, therefore, is limiting birth to the desired number of children.

The methods of birth chosen have to suit the lifestyle, age, state of health, the need to avoid pregnancy and peculiar relationship in the family. Thus, before choosing a birth control method, there is a need to assess the acceptability, effectiveness and side effects of the methods. However, scholars (Bryan et al., 2005) identified modern birth control methods and traditional birth control methods. The modern method is the artificial methods of controlling birth while traditional birth control is the congenital method of controlling birth. Natural birth control is based on identifying the woman's fertile days and the timing of sexual intercourse. Generally, the natural methods include calendar (rhythm) method, the basal body temperate method, the cervical mucus method, the symptom-thermal method and lactation (Mccweeney, 2011). Modern methods include the use of contraceptive devices (Bryan et al., 2005). Evans, Patel, and Stranton (2007) classified the contraceptives for men as coitus interrupts (withdrawal), the condom, vasectomy among others and contraceptives for women which include - douching, vaginal jellies or cream, the vaginal diaphragm etc. The methods specified for women include a pill that causes temporary menstrual suppression, injectable hormones, a vaginal ring and a patch (Brayan et al., 2005). However, birth control methods must be methods that prevent a fertilized egg from implanting in the uterine wall (such as IUD in some instances and emergency contraceptive pills) and methods that remove the conceptus - the fertilized egg (embryo) or fetus from the uterus (such as RU - 486 and surgical abortions) are common among married people( Brayan et al., 2005).

Married peopled are people of opposite or the same sex who agreed to live together and share marital rite as well. Married people are individual who enjoys intimate union and equal partnership in a household (Giami, 2002). Giami noted that married peoples' level of knowledge of birth control methods influences their condition of childbearing. Anyanwu and Ofordile (2012) submitted that married people are people who obliged to the natural institution of childbearing with the sharing of responsibilities. In this study, married people are people living together as husband and wife. However, married people exercise birth control (Ndom, Igbokwe, \&Ekeruo, 2012) mostly in the form of family planning.

Family planning involves action embarked upon by married people to project the number, spacing of children and timing by using birth control. Therefore, family planning deals with the ability of couples and individuals to hope for and achieve their dream number of children by the timing and spacing of their birth (Omolase, Faturoti, \& Omolase, 2009). The authors further stated that the availability of family planning does more than enabling married people to limit family size. It also safeguards individual health and rights and improves the quality of life of couples and their children (Omolase et al., 2009). Therefore, family planning is the measures taken by couples to project the number, spacing of children and spacing by using birth control. Again, family planning is most adopted by couples who wish to limit the number of children they want to have and control the timing of pregnancy also known as spacing of children (Olaitan, 2009). The author further stated that family planning encompasses sterilization, as well as pregnancy termination. It also includes raising a child with methods that require a significant amount of resources namely, time, social, financial and environmental. Family planning measures are designed to regulate the number and spacing of children within a family, largely to curb population growth and ensure each family has access to limited resources (Olaitan, 2009). According to Ezugwu and Omeje (2010), family planning means having the number of children that one can afford to bring up well. The authors affirmed that family planning is birth line by preference either for the purpose of spacing pregnancy or for limiting family size. Therefore, family planning includes the plan to determine the spacing of one's children and the number by using birth control. To this end, family planning is having children optionally not by accident (Ezugwu \& Omeje, 2010). In this study, family planning is seen as any action by couples to regulate birth. 
Family planning is credited primarily for its role in bringing down the birth rates globally and particularly in developing countries. From 1950 to 2000, global fertility has fallen by about half from five children per woman in 1950-1955 to 2.7 children in 2000-2005 (United Nation, 2005a). However, less well recognized is the contribution of family planning to the major social change around the world whereby couples are empowered in regulating their fertility instead of considering it as a matter of God's will or destiny. Family planning has also an impact that is often glossed over (United Nation, 2005a). It is known to have been practised for centuries long before the advent of modern methods of contraception. The earlier methods used by men and women to regulate their fertility included coitus interrupts (withdrawal of the pennies from the vagina prior to ejaculation) abstinence (abstaining from sex altogether or around the time of ovulation), herbs and amulets (Planned Parenthood Federation of America, 2006).

It seems that the lack of knowledge of family planning is on the increase. Okere and Onyechi (2010) pointed out that lack of family planning could cause reproductive health problems, unplanned or untimed pregnancy, abortions, school drop-out, the burden on individual welfare and scarce government resources. According to World Health Organization (2015), about 222 million "unsafe" abortions that occur each year cause an estimated 47,000 maternal deaths - mostly in developing countries and leads to short-term lifelong disabilities in many women. It has been estimated that maternal death could be averted through the use of effective family planning by women wishing to postpone or cease further childbearing. About 22 million women in developing countries are thought to have an unmet need for a method of family planning. This unmet need is particularly prevalent in certain populations, especially sexually active adolescents, individuals with low socioeconomic status, those living in rural communities and those coping with conflicts and disasters (Moazzam, Ali, Armandor, Asma, Maiofestin, \& Mardeen, 2013). The most common sources of family planning knowledge are mass media, health workers, friends among others (Ikechebelu, Ikechebelu, \& Obiajulu, 2005). The objective of family planning services is to encourage couple to take responsible decisions about pregnancy and to enable them achieve their wishes with regards to preventing unwanted pregnancy, securing desired pregnancy, spacing pregnancies, limiting the size of their family and ultimately promoting responsible parenthood, controlling the population and improving the quality of the life people (Ikechebelu \& Obiajulu, 2005).

However, despite the high potential demand for family planning services as revealed in Nigeria's Demographic and Health Survey (Bankole, Rodriguez, \& Westoff, 1996), the birth control prevalence rate (CPR) is low among married couples (Udigwe, Udigwe, \& Ikechebelu, 2002), as a result of poor educational background (Olaitan, 2011), lack of adequate awareness and knowledge, as well as poor attitudes toward birth control and family planning (Ngwu, 2014), and religion (Eze \& Okeke, 2014). Moreover, the World Health Organization (2015) found that birth control is much lower in the developing countries and that $12 \%$ of married women are estimated to have an unmet need for family planning. Evidence shows that in the area of the present study, some women are not knowledgeable about family planning and that religion plays an active role in the adoption of family planning practices in Nsukka local government area of Enugu State (Eze \& Okeke, 2014). Ngwu (2014), Eze and Okeke (2014) observed that the standard of education, cultural background, age, occupation among others, affect married couple choice on the effective adoption of family planning techniques. Also, Bryan, Christine, Barbara and William (2005) stated that for many married people the search for an "ideal" method of birth control could be frustrating, some methods pose health risks, others run counter to religious or moral beliefs and still others are inconvenient, aesthetically displeasing or too expensive as well as gender.

Studies have shown that gender plays an important role in birth control and family planning. Gender refers to socially and culturally constructed expectations and obligation which underline male and female relations in societies. The different ways in which males and females behave are linked to but not necessarily determined by their biological sex (Schneider et al., 2004). In fact, people are identified as male or female on the basis of physical structures, which are determined by chromosomes, glands and hormones. This labelling starts at birth and is the first step in the process of developing gender identity, that is, a sense of being male or female and what that means in one's society (Nwosu, 2008). In the context of this research work, gender refers to socially and culturally approved feminine and masculine roles. Male gender norms are widely accepted as factors influencing a range of family planning reproductive health behaviours (Garg \& Sigh, 2014). Integrating gender equality into the family planning programme will improve the health of the nation and gender equality (Garg \& Sigh, 2014).

Undelikwo, Osonwa, Ushie, and Osonwa (2013) asserted that researchers have revealed that Filipino men highly determine their wives resolve to embark on family planning and that, the husband's approval is important to their wife's adoption of a method. They went on to state that, according to the 2003 Philippine National Demographic and Health Survey, some Filipino women mentioned husband's disapproval of family planning practice as one of the courses of not employing family planning. In any controversy over the timing of pregnancy and the number of 
children, the husband's will always hold. Female partners are believed or expected to obey their husband's decision about family planning matters to keep marital harmony.

From the discussion so far, it is clear there is a need for controlling birth for the sake of family planning. Lack of birth control in Enugu state Nigeria may result to continued rapid population growth which consequently results to higher pressure on employment chances, food, land, clean water, housing and other expedients which will become more scarce with increasing population, according to Eke, Ofori, and Tabansi (2011). Also pointed out by WACOL is that many of unplanned births are connected with deficient information and frequentness of a lot of misinformation amidst people who are married and those to whom they run to for help. As Beguy (2010) reported, the economic crisis has situated families to urbanization with a slum reduction on the number of childbearing as seen in the rural areas. Although, Rathi (2006) was of the opinion that $40 \%$ of Africa would like to avoid pregnancy thereby reducing the efficacy of modern birth control. Therefore, going by the above assertion, Nsukka may have little knowledge of birth control but may find it difficult to utilize such knowledge against their belief of childbearing as a gift from God. More so, they may see it as a way to eliminate their natural gift among others of their claim. Thus, the situation is still worrisome to married couples, governments, counsellors, social welfare officers, community health workers and researchers.

Considering the effects of non-use of birth control measures for family planning that have been documented, one could say that research on the knowledge level of birth control methods and its usage for family planning among married people is still inconclusive. Nevertheless, it is important to recognize that previous studies on these issues use different designs, different sampling, were conducted in different countries at different times and with different types of results. It may be possible that lack of knowledge of birth control methods, its side effects, the extent of its usage, and measures to enhance family planning among married people accounted for the disparities. Hence, the present study sought to examine the knowledge and use of birth control methods of family planning by married people in Nsukka Education Zone.

\subsection{Research Questions}

The study was guided by the following research questions.

1).What is the knowledge level of female and male married people on the idea of common birth control methods of family planning in Nsukka Education Zone?

2).To what extent do male and female married people apply birth control measures for planning family in Nsukka Education Zone?

3).What are the problems in the use of birth control methods of family planning by male and female respondents in Nsukka Education Zone?

4).What measures can be adopted to enhance family planning among male and female married people in Nsukka Education Zone?

\subsection{Hypotheses}

The hypotheses that follow were put to direct the study and were tested at 0.05 level of significance.

$\mathrm{HO}_{1}$ : There is no significant difference in the knowledge level of female and male married people on birth control methods for family planning in Nsukka Education Zone.

$\mathrm{H}_{2}$ : There is no significant difference in the mean responses of male and female married people on the extent to which married people apply birth control measures for family planning in Nsukka education zone.

$\mathrm{HO}_{3}$ : There is no significant difference in the mean responses of male and female married people on the problems in the use of birth control methods for family planning in Nsukka Education Zone.

$\mathrm{HO}_{4}$ : There is no significant difference in the mean responses of female and male married people on methods that can be applied to improve family planning amidst married people in Nsukka Education Zone? 


\subsection{Conceptual Framework}

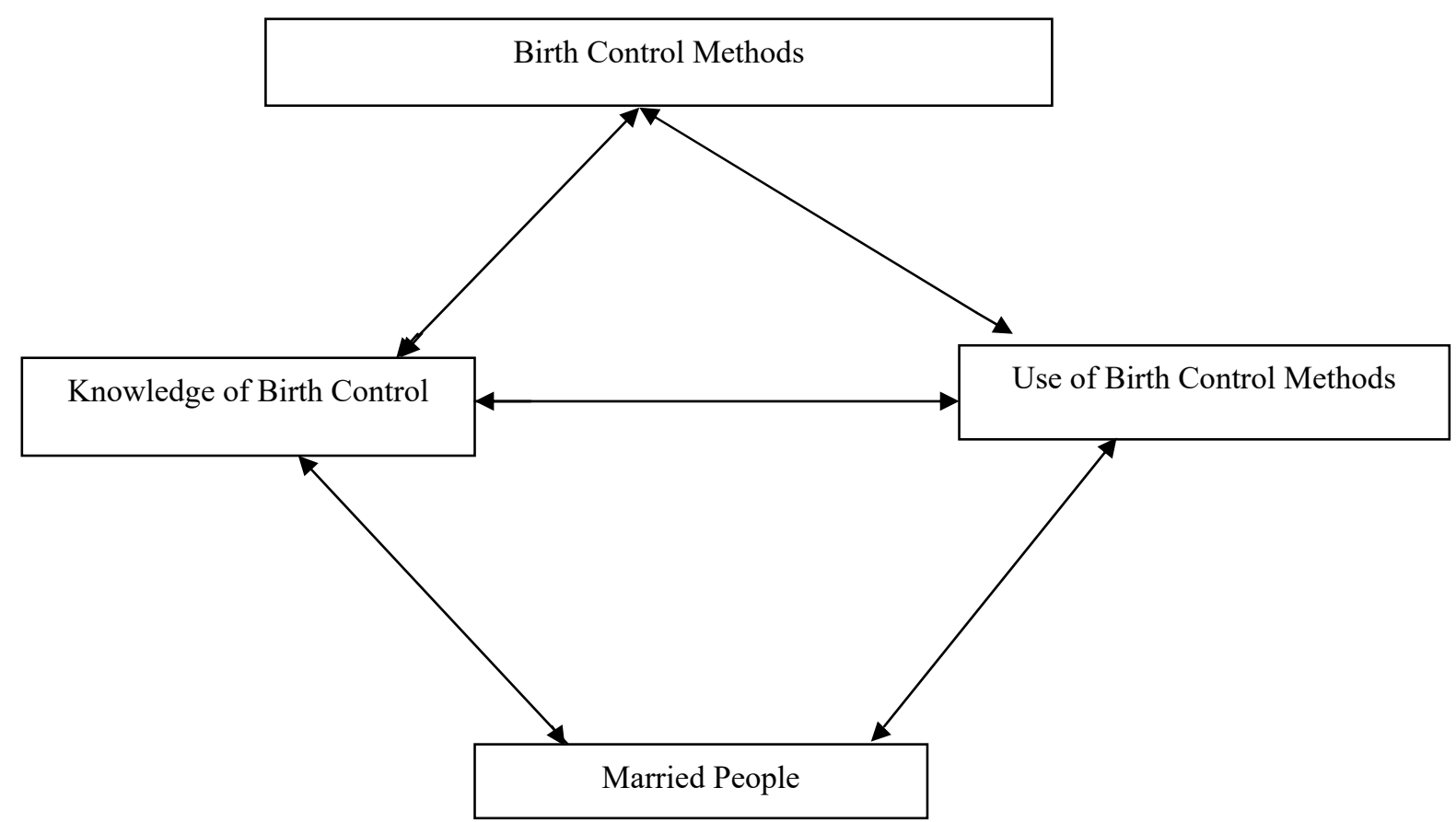

Figure 1. Schematic Representation of the Variables

The diagram above shows the schematic representation of the variables discussed in the study. The knowledge married people have about birth control determines or influences their choice of birth control. The availability of birth control methods also determines the extent of married people's use of birth control methods. The use of birth control methods by married people is dependent on their level of knowledge and availability of the birth control methods.

\section{Materials and Methods}

\subsection{Design of the Study}

A descriptive survey design was used for this study. Nworgu (2015) sees a descriptive survey as a design which aims at collecting data and describing in a systematic manner the characteristic features or facts about a given population. Therefore, descriptive survey design was used in the study since the researchers was interested in investigating a large number of people and it provided the researchers with the opportunity of gathering data from a significant number of the population to enable favourable generalization about the entire population.

\subsection{Area of the Study}

This investigation was conducted in Nsukka Education zone, Enugu State. Nsukka Education zone has been the seat of civil service right from the colonial period to date. Nsukka has a number of industries, schools (Nursery, Primary, Secondary and Tertiary), business houses (hawks, firms, finance houses) and large markets. The choice of the area was based on the consideration that, this area has a good concentration of literate married people with a large number of children and they seem to find it extremely very difficult to make both ends meet due to their large families

\subsection{Population of the Study}

The population for this study comprised 4450 married people who registered for marriage from 2010 to 2017 in Nsukka Education Zone, Enugu State.Nsukka has 1990; Igbo Etiti has 1392 and Uzo-Uwani has 1068 according to (Nsukka Local Government Marriage Registry, 2017).

\subsection{Sample and Sampling Techniques}

The sample for this study comprised 445 (210 married males and 235 married female) people from Nsukka Education Zone which is $10 \%$ of the population stated above. The sample was selected using a multi-stage 
sampling procedure. At stage one; proportionate random stratified sampling procedure was used to select $10 \%$ of the population from the three Local Government Area that was used in the study. The relative proportions of the sample from each LGA were 199, 139, and 107 from Nsukka, Igbo-Etiti and Uzo-Uwani respectively. The choice of this procedure was to ensure that each of the three Local Government Areas has equal representativeness of sample relative to the population. At stage two, simple random sampling (paper slip method) was used to select 445 (Nsukka=199, Igbo Etiti = 139 and Uzo-Uwani =107) married people for the study. The choice of this technique was to give every married people in the study area equal chance of participating in the study.

\subsection{Instrument for Data Collection}

The instrument for data collection was a questionnaire developed by the researchers. The questionnaire was titled "Knowledge and use of birth control methods for family planning questionnaire (KUBCM)". It has two sections Section A was used to elicit information about personal data, while section B containing 40 items in four clusters was used to gather information on the birth control methods of family planning used by married people. Cluster 1 dealt with the knowledge of birth control methods used by married people for family planning. It was constructed on a 4 point rating scale of: Know Very Well (KVW) 4; Know Well (KW) 3; Know Very Little (KVL) 2; Does not Know (DNK) 1. Cluster 2 elicited information on the extent of use of birth control methods of family planning by married people. Its response options were Very Great Extent (VGE) 4; Great Extent (GE) 3, Low Extent (LE) 2 and Very Low Extent (VLE) 1. Cluster 3 dealt with problems in the use of birth control methods of family planning by married people. Its response options were Strongly Agree (SD) 4, Agree (A) 3, Disagree (D) 2 and Strongly Disagree (SD) 1. Cluster 4 which is concerned with measures to enhance family planning among married people also has four response options of Strongly Agree (SA) 4; Agree (A) 3; Disagree (D) 2; Strongly Disagree (SD) respectively.

\subsection{Validation of the Instrument}

The instrument was face validated by three experts from the University of Nigeria, Nsukka. Two of the experts were from Educational Foundations and one was from Measurement and Evaluation. The experts were to find out if the instrument would measure what it intended to measure. They were requested to examine the instrument to ensure that it would help the researchers collect pertinent data for answering the research questions and testing the null hypotheses. The experts examined the instrument in terms of clarity, suitability and relevance. After the examination of the instrument, they restructured the language, removed ambiguous words in the instrument that may have hindered eliciting the information needed for the study, made relevant corrections and gave suggestions to ensure that the objectives of the study were realized. The researchers modified the instrument based on their suggestions. Their comments and corrections helped a lot in the improvement of the final draft of the instrument.

\subsection{Reliability of the Instrument}

The instrument was administered to 25 married people selected from Nkanu West Education Zone. This zone was chosen because it is outside the area of study and married people from there have the same characteristics as the respondents under study. The population phenomena are the same because it is densely populated. They also have an attachment to rearing many children. The instrument was administered once and the data was collected and analyzed using Cronbach alpha statistics. The reliability coefficient obtained was .67 for cluster A,. 83 for cluster $\mathrm{B}, .73$ for cluster $\mathrm{C}$ and .68 for cluster D. The cumulative coefficient of the instrument was .85 which shows that the instrument is reliable.

\subsection{Method of Data Collection}

The researchers established rapport with respondents by the brief introduction of self stating clearly the researchers' mission. The instrument was administered to the respondents by the researchers and two research assistants using on the spot administration and retrieval to lessen the incidence of instrument loss. The research assistants were briefed to interpret the instrument to the low literate segment of respondents who may find it difficult to do so by themselves. However, where the respondents could not complete the questionnaire immediately, the research assistants helped retrieve it later.

\subsection{Method of Data Analysis}

Mean and standard deviation was used to answer all the research questions. For research questions 1 and 2, real limit of mean was used. For research questions 3 and 4, any response with a mean rating of 2.5 and above was accepted while the mean rating below 2.5 was not be accepted. 
The real limits of means were as follows;

$$
\begin{array}{llll}
\text { KVW } & = & \text { Know Very Well } & 3.50-4.00 \\
\text { KW }= & \text { Know Well } & 2.50-3.49 \\
\text { KVL } & =\quad \text { Know Very Little } & 1.50-2.49 \\
\text { DNK } & =\quad \text { Does Not Know } & 1.00-1.49 \\
\mathrm{VGE}= & \text { Very Great Extent } & 3.50-4.00 \\
\mathrm{GE}= & \text { Great Extent } & 2.50-3.49 \\
\mathrm{LE}= & \text { Low Extent } & 1.50-2.49 \\
\mathrm{VLE}= & \text { Very Low Extent } & 1.00-1.49
\end{array}
$$

T-test statistics was used in testing the null hypotheses formulated for the study at 0.05 level of significance. The decision rule for testing the hypotheses was: reject the null hypothesis if the exact probability value (p-value) is

\begin{tabular}{|c|c|c|c|c|c|c|c|c|}
\hline \multirow{3}{*}{$\mathbf{S} / \mathbf{N}$} & \multirow{3}{*}{ Knowledge of common birth control methods } & \multirow{2}{*}{\multicolumn{2}{|c|}{$\begin{array}{l}\text { Male } \\
\mathbf{N}=\mathbf{2 1 0}\end{array}$}} & \multirow{2}{*}{\multicolumn{2}{|c|}{$\begin{array}{l}\text { Female } \\
\mathbf{N}=\mathbf{2 3 5}\end{array}$}} & \multirow{2}{*}{\multicolumn{2}{|c|}{$\begin{array}{l}\text { Overall } \\
\mathrm{N}=445\end{array}$}} & \multirow[b]{3}{*}{ Dec. } \\
\hline & & & & & & & & \\
\hline & & $\overline{\boldsymbol{X}}$ & SD & $\overline{\boldsymbol{X}}$ & SD & $\overline{\boldsymbol{X}}$ & SD & \\
\hline 1 & Abstinence -refraining from sexual intercourse & 3.68 & 0.46 & 3.51 & 0.50 & 3.59 & 0.49 & KVW \\
\hline 2 & $\begin{array}{l}\text { Douching- washing the vagina with water or medicated liquids after sexual } \\
\text { intercourse. }\end{array}$ & 2.05 & 0.71 & 2.21 & 0.65 & 2.13 & 0.68 & KVL \\
\hline 3 & Lactation- continued breastfeeding to avoid pregnancy. & 2.79 & 1.11 & 3.33 & 0.87 & 3.07 & 1.02 & KW \\
\hline 4 & $\begin{array}{l}\text { The pill or oral contraceptives- which contains synthetic hormones that } \\
\text { suppress ovulation }\end{array}$ & 2.25 & 0.64 & 2.38 & 0.64 & 2.32 & 0.64 & KW \\
\hline 5 & $\begin{array}{l}\text { Condom- flexible sheet of latex rubber fits over the erect penis to prevent } \\
\text { semen from being transmitted. }\end{array}$ & 2.79 & 1.12 & 3.05 & 0.98 & 2.92 & 1.06 & KW \\
\hline 6 & Fertility awareness method- this relies on a woman's reproductive cycle. & 3.40 & 0.78 & 3.21 & 0.78 & 3.30 & 0.78 & KW \\
\hline 7 & $\begin{array}{l}\text { Withdrawal (coitus interruptus) - removing the penis from the vagina before } \\
\text { ejaculation. }\end{array}$ & 2.80 & 1.08 & 3.11 & 0.89 & 2.97 & 1.00 & KW \\
\hline 8 & $\begin{array}{l}\text { Intrauterine Device (IUD) - a device that is inserted into uterus prevent } \\
\text { conception for } 1-12 \text { years. }\end{array}$ & 1.77 & 0.42 & 1.89 & 0.30 & 1.84 & 0.37 & KVL \\
\hline 9 & $\begin{array}{l}\text { Injectable contraceptive (DMPA) provides protection from pregnancy for } 3 \\
\text { months. }\end{array}$ & 2.94 & 1.04 & 3.23 & 0.78 & 3.09 & 0.92 & KW \\
\hline \multirow[t]{2}{*}{10} & Vasectomy- prevents the passage of sperm into seminal fluid. & 2.21 & 0.78 & 2.34 & 0.65 & 2.28 & 0.71 & KVL \\
\hline & Cluster Mean & 2.66 & 0.40 & 2.82 & 0.27 & 2.75 & 0.34 & KW \\
\hline
\end{tabular}
less than the 'a priori' probability value (that is, the level of significance); otherwise, accept.

\section{Results}

\subsection{Research Question One}

What is the knowledge level of female and male married people on the idea of common birth control methods of family planning in Nsukka Education Zone?

Table 1. Mean ratings and standard deviation of respondents on the knowledge of common birth control methods for family planning

Key: KVW = Know Very Well, KW = Know Well, KVL = Know Very Little.

The result of the study as presented in Table 1 shows the mean ratings and standard deviations of the respondents on the knowledge of common birth control methods for family planning in Nsukka Education Zone. The result of the study showed that item 1 for both male and female respondents had a mean rating within the range of 3.50 4.00 set as a criterion for Know Very Well. This implies that the male and female respondents know very well that abstinence - refraining from sexual intercourse is a common birth control methods for family planning. Also, 
Items 3-7 and 9 had mean ratings within the range of 2.50-3.49 set as a criterion for Know Well. These also mean that both male and female respondents they know well that Lactation- continued breastfeeding to avoid pregnancy, the pill or oral contraceptives- which contains synthetic hormones that suppress ovulation, condom- flexible sheet of latex rubber fits over the erect penis to prevent semen from being transmitted and withdrawal (coitus interrupts) - removing the penis from the vagina before ejaculation among others are common birth control methods for family planning. However, items 2,8 and 10 had a mean rating within the range of $1.50-2.49$ set as criterion for Know Very Little, implying that both male and female respondents know very little that douching- washing the vagina with water or medicated liquids after sexual intercourse and vasectomy- prevents passage of sperm into seminal fluid are common birth control methods for family planning. The overall clusters mean of 2.75 with a standard deviation of 0.34 shows that the respondents (both male and female) have knowledge of common birth control methods for family planning in Nsukka Education Zone.

\subsection{Hypothesis One}

There is no significant difference in the mean response of male and female about knowledge of common birth control methods for family planning in Nsukka Education Zone.

Table 2. T-testanalysis of the difference between the mean responses of the male and female married people about knowledge of common birth control methods for family planning

\begin{tabular}{|c|c|c|c|c|c|c|c|c|c|}
\hline \multirow{2}{*}{$\mathbf{S} / \mathbf{N}$} & \multirow{2}{*}{ Knowledge of common birth control methods } & \multicolumn{2}{|l|}{ Male } & \multicolumn{2}{|c|}{ Female } & \multirow{2}{*}{ t-cal } & \multirow{2}{*}{ df } & \multirow{2}{*}{ Sig } & \multirow{2}{*}{ Dec } \\
\hline & & $\overline{\boldsymbol{X}}$ & SD & $\overline{\boldsymbol{X}}$ & SD & & & & \\
\hline 1 & Abstinence -refraining from sexual intercourse & 3.68 & 0.46 & 3.51 & 0.50 & 3.67 & 443 & 0.00 & $\mathbf{S}$ \\
\hline 2 & $\begin{array}{l}\text { Douching- washing the vagina with water or medicated } \\
\text { liquids after sexual intercourse. }\end{array}$ & 2.05 & 0.71 & 2.21 & 0.65 & -2.40 & 443 & 0.01 & $\mathrm{~S}$ \\
\hline 3 & Lactation- continued breastfeeding to avoid pregnancy. & 2.79 & 1.11 & 3.33 & 0.87 & -5.68 & 443 & 0.00 & $\mathrm{~S}$ \\
\hline 4 & $\begin{array}{l}\text { The pill or oral contraceptives- which contains synthetic } \\
\text { hormones that suppress ovulation }\end{array}$ & 2.25 & 0.64 & 2.38 & 0.64 & -2.12 & 443 & 0.03 & $\mathrm{~S}$ \\
\hline 5 & $\begin{array}{l}\text { Condom- flexible sheet of latex rubber fits over the erect } \\
\text { penis to prevent semen from being transmitted. }\end{array}$ & 2.79 & 1.12 & 3.05 & 0.98 & -2.60 & 443 & 0.00 & $\mathrm{~S}$ \\
\hline 6 & $\begin{array}{l}\text { Fertility awareness method- this relies on a woman's } \\
\text { reproductive cycle. }\end{array}$ & 3.40 & 0.78 & 3.21 & 0.78 & 2.64 & 443 & 0.00 & $\mathrm{~S}$ \\
\hline 7 & $\begin{array}{l}\text { Withdrawal (coitus interruptus) - removing the penis from } \\
\text { the vagina before ejaculation. }\end{array}$ & 2.80 & 1.08 & 3.11 & 0.89 & -3.24 & 443 & 0.00 & $\mathrm{~S}$ \\
\hline 8 & $\begin{array}{l}\text { Intrauterine Device (IUD) - a device that is inserted into } \\
\text { uterus prevent conception for } 1-12 \text { years. }\end{array}$ & 1.77 & 0.42 & 1.89 & 0.30 & -3.51 & 443 & 0.00 & $\mathrm{~S}$ \\
\hline 9 & $\begin{array}{l}\text { Injectable contraceptive (DMPA) provides protection from } \\
\text { pregnancy for } 3 \text { months. }\end{array}$ & 2.94 & 1.04 & 3.23 & 0.78 & -3.29 & 443 & 0.00 & $\mathrm{~S}$ \\
\hline \multirow[t]{2}{*}{10} & $\begin{array}{l}\text { Vasectomy- prevents the passage of sperm into seminal } \\
\text { fluid. }\end{array}$ & 2.21 & 0.78 & 2.34 & 0.65 & -1.92 & 443 & 0.05 & $\mathrm{~S}$ \\
\hline & Cluster t & 2.66 & 0.40 & 2.82 & 0.27 & -4.83 & 443 & 0.00 & $\mathrm{~S}$ \\
\hline
\end{tabular}

The result of the study as presented in Table 2 shows the t-test analysis of the significant difference in the mean response of male and female respondents on the knowledge of common birth control methods for family planning in Nsukka Education Zone. The cluster t-value of -4.83 with a degree of freedom of 443 and significant value of 0.00 was obtained. Since the significant value of 0.00 is less than 0.05 set as a level of significance, this means the result is significant. The null hypothesis which stated that there is no significant difference in the mean response of male and female knowledge of common birth control methods for family planning in Nsukka Education Zone is rejected. An inference drawn therefore is that there was a significant difference in the mean response of male and female knowledge of common birth control methods for family planning in Nsukka Education Zone with the female respondents having a higher mean rating than their male counterparts. 


\subsection{Research Question Two}

To what extent do male and female married people make use of birth control methods for family planning in Nsukka Education Zone?

Table 3. Mean ratings and standard deviation of respondents on the extent married people make use of birth control methods for family planning

\begin{tabular}{|c|c|c|c|c|c|c|c|c|}
\hline \multirow{3}{*}{$\mathbf{S} / \mathbf{N}$} & \multirow{3}{*}{ Use of birth control methods } & \multirow{2}{*}{\multicolumn{2}{|c|}{$\begin{array}{l}\text { Male } \\
\mathbf{N}=\mathbf{2 1 0}\end{array}$}} & \multirow{2}{*}{\multicolumn{2}{|c|}{$\begin{array}{l}\text { Female } \\
\mathbf{N}=\mathbf{2 3 5}\end{array}$}} & \multirow{2}{*}{\multicolumn{2}{|c|}{$\begin{array}{l}\text { Overall } \\
N=445\end{array}$}} & \multirow[b]{3}{*}{ Dec. } \\
\hline & & & & & & & & \\
\hline & & $\bar{X}$ & SD & $\bar{X}$ & SD & $\overline{\boldsymbol{X}}$ & SD & \\
\hline 1 & Abstinence - refraining from sexual intercourse & 2.49 & 1.15 & 3.14 & 0.98 & 2.84 & 1.11 & GE \\
\hline 2 & $\begin{array}{l}\text { Douching- washing the vagina with water or medicated liquids after sexual } \\
\text { intercourse. }\end{array}$ & 2.67 & 1.12 & 3.31 & 0.88 & 3.01 & 1.05 & GE \\
\hline 3 & Lactation- continued breastfeeding to avoid pregnancy. & 2.19 & 0.71 & 2.44 & 0.60 & 2.32 & 0.67 & LE \\
\hline 4 & $\begin{array}{l}\text { The pill or oral contraceptives- which contains synthetic hormones that } \\
\text { suppress ovulation }\end{array}$ & 2.15 & 0.61 & 2.30 & 0.55 & 2.23 & 0.58 & LE \\
\hline 5 & $\begin{array}{l}\text { Condom- flexible sheet of latex rubber fits over the erect penis to prevent } \\
\text { semen from being transmitted. }\end{array}$ & 3.65 & 0.47 & 3.52 & 0.50 & 3.58 & 0.49 & VGE \\
\hline 6 & Fertility awareness method- this relies on woman's reproductive cycle. & 2.81 & 1.12 & 3.26 & 0.80 & 3.05 & 0.99 & GE \\
\hline 7 & $\begin{array}{l}\text { Withdrawal (coitus interruptus) - removing the penis from the vagina before } \\
\text { ejaculation. }\end{array}$ & 2.83 & 1.08 & 3.35 & 0.86 & 3.10 & 1.00 & GE \\
\hline 8 & $\begin{array}{l}\text { Intrauterine Device (IUD) - a device that is inserted into uterus prevent } \\
\text { conception for } 1-12 \text { years. }\end{array}$ & 3.11 & 1.00 & 3.28 & 0.85 & 3.20 & 0.93 & GE \\
\hline 9 & $\begin{array}{l}\text { Injectable contraceptive (DMPA) provides protection from pregnancy for } 3 \\
\text { months. }\end{array}$ & 3.12 & 0.91 & 3.44 & 0.68 & 3.29 & 0.81 & GE \\
\hline \multirow[t]{2}{*}{10} & Vasectomy- prevents passage of sperm into seminal fluid. & 2.82 & 0.94 & 3.40 & 0.87 & 3.13 & 0.95 & GE \\
\hline & Cluster Mean & 2.78 & 0.39 & 3.14 & 0.25 & 2.97 & 0.37 & GE \\
\hline
\end{tabular}

The results of the study as presented in Table 3 show the mean ratings and standard deviations of the respondents on the extent male and female married people make use of birth control methods for family planning in Nsukka Education Zone. The result of the study showed that both male and female respondents make use of Condom- a flexible sheet of latex rubber fits over the erect penis to prevent semen from being transmitted to a very great extent. This is because the mean rating for item 5 is within the range of 3.50-4.00 set as criterion for Very Great Extent. Also, Items 1-2 and 6-10 had mean ratings within the range of 2.50-3.49 set as criterion for Great Extent. These mean that the respondents make use of abstinence - refraining from sexual intercourse, douching- washing the vagina with water or medicated liquids after sexual intercourse, withdrawal (coitus interruptus) - removing the penis from the vagina before ejaculation and Intrauterine Device (IUD) - a device that is inserted into uterus prevent conception for 1-12 years to a great extent. The result also shows that items 3 and 4 had mean rating within the range of 1.50-2.49 set as criterion for Low extent, implying that the respondents make use of Lactationcontinued breast feeding to avoid pregnancy and the pill or oral contraceptives- which contains synthetic hormones that suppress ovulation to a low extent. The overall clusters mean of 2.97 with a standard deviation of 0.37 shows that the respondents (both male and female) make use of birth control methods for family planning in Nsukka Education Zone to a great extent.

\subsection{Hypothesis Two}

There is no significant difference in the mean responses of male and female married people on the extent to which married people make use of birth control methods for family planning in Nsukka education zone. 
Table 4. T-test analysis of the difference in the mean responses of male and female married people on the extent to which married people make use of birth control methods for family planning

\begin{tabular}{|c|c|c|c|c|c|c|c|c|c|}
\hline \multirow{2}{*}{$\mathbf{S} / \mathbf{N}$} & \multirow{2}{*}{$\begin{array}{l}\text { Knowledge of Common Birth Control } \\
\text { Methods }\end{array}$} & \multicolumn{2}{|c|}{ Male } & \multicolumn{2}{|c|}{ Female } & \multirow{2}{*}{ t-cal } & \multirow{2}{*}{ df } & \multirow{2}{*}{ Sig } & \multirow{2}{*}{ Dec } \\
\hline & & $\bar{X}$ & SD & $\bar{X}$ & SD & & & & \\
\hline 1 & Abstinence -refraining from sexual intercourse & 2.49 & 1.15 & 3.14 & 0.98 & -6.47 & 443 & 0.00 & $\mathbf{S}$ \\
\hline 2 & $\begin{array}{l}\text { Douching- washing the vagina with water or } \\
\text { medicated liquids after sexual intercourse. }\end{array}$ & 2.67 & 1.12 & 3.31 & 0.88 & -6.73 & 443 & 0.00 & $\mathrm{~S}$ \\
\hline 3 & $\begin{array}{l}\text { Lactation- continued breastfeeding to avoid } \\
\text { pregnancy. }\end{array}$ & 2.19 & 0.71 & 2.44 & 0.60 & -4.02 & 443 & 0.00 & $\mathrm{~S}$ \\
\hline 4 & $\begin{array}{l}\text { The pill or oral contraceptives- which contains } \\
\text { synthetic hormones that suppress ovulation }\end{array}$ & 2.15 & 0.61 & 2.30 & 0.55 & -2.72 & 443 & 0.00 & $\mathrm{~S}$ \\
\hline 5 & $\begin{array}{l}\text { Condom- flexible sheet of latex rubber fits over } \\
\text { the erect penis to prevent semen from being } \\
\text { transmitted. }\end{array}$ & 3.65 & 0.47 & 3.52 & 0.50 & 2.86 & 443 & 0.00 & $\mathrm{~S}$ \\
\hline 6 & $\begin{array}{l}\text { Fertility awareness method- this relies on } \\
\text { woman's reproductive cycle. }\end{array}$ & 2.81 & 1.12 & 3.26 & 0.80 & -4.93 & 443 & 0.00 & $\mathrm{~S}$ \\
\hline 7 & $\begin{array}{l}\text { Withdrawal (coitus interruptus) - removing the } \\
\text { penis from the vagina before ejaculation. }\end{array}$ & 2.83 & 1.08 & 3.35 & 0.86 & -5.63 & 443 & 0.00 & $\mathrm{~S}$ \\
\hline 8 & $\begin{array}{l}\text { Intrauterine Device (IUD) - a device that is } \\
\text { inserted into uterus prevent conception for } 1-12 \\
\text { years. }\end{array}$ & 3.11 & 1.00 & 3.28 & 0.85 & -1.89 & 443 & 0.05 & $\mathrm{~S}$ \\
\hline 9 & $\begin{array}{l}\text { Injectable contraceptive (DMPA) provides } \\
\text { protection from pregnancy for } 3 \text { months. }\end{array}$ & 3.12 & 0.91 & 3.44 & 0.68 & -4.24 & 443 & 0.00 & $\mathrm{~S}$ \\
\hline \multirow[t]{2}{*}{10} & $\begin{array}{l}\text { Vasectomy- prevents passage of sperm into } \\
\text { seminal fluid. }\end{array}$ & 2.82 & 0.94 & 3.40 & 0.87 & -6.71 & 443 & 0.00 & $\mathrm{~S}$ \\
\hline & Cluster t & 2.78 & 0.39 & 3.14 & 0.25 & -11.48 & 443 & 0.00 & $\mathbf{S}$ \\
\hline
\end{tabular}

The result of the study as presented in Table 4 shows the t-test analysis of the significant difference in the mean response of male and female respondents on the extent to which married people make use of birth control methods for family planning in Nsukka education zone. The cluster $\mathrm{t}$-value of -11.48 with a degree of freedom of 443 and a significant value of 0.00 were obtained. Since the significant value of 0.00 is less than 0.05 set as level of significance, this means the result is significant. The null hypothesis which stated that there is no significant difference in the mean responses of male and female married people on the extent to which married people make use of birth control methods for family planning in Nsukka education zone is rejected. Inference drawn therefore is that there was a significant difference in the mean responses of male and female married people on the extent to which married people make use of birth control methods for family planning in Nsukka education zone.

\subsection{Research Question Three}

What are the problems in the use of birth control methods for family planning by male and female respondents in Nsukka Education Zone? 
Table 5. Mean Ratings and standard deviation of respondents on the problems in the use of birth control methods for family planning

\begin{tabular}{|c|c|c|c|c|c|c|c|c|}
\hline \multirow[t]{2}{*}{$\mathbf{S} / \mathbf{N}$} & \multirow[t]{2}{*}{ Problems in the use of birth control methods } & \multicolumn{2}{|c|}{$\begin{array}{l}\text { Male } \\
\mathbf{N}=\mathbf{2 1 0}\end{array}$} & \multicolumn{2}{|c|}{$\begin{array}{l}\text { Female } \\
\mathbf{N}=\mathbf{2 3 5}\end{array}$} & \multicolumn{2}{|c|}{$\begin{array}{l}\text { Overall } \\
\mathrm{N}=445\end{array}$} & \multirow[t]{2}{*}{ Dec. } \\
\hline & & $\bar{X}$ & SD & $\bar{X}$ & SD & $\overline{\boldsymbol{X}}$ & SD & \\
\hline 1 & $\begin{array}{l}\text { Only-child syndrome/I am the only child, therefore, I will give birth as long as } \\
\text { pregnancies come }\end{array}$ & 2.28 & 0.64 & 2.23 & 0.58 & 2.25 & 0.61 & $\mathrm{D}$ \\
\hline 2 & Fear of side effects & 2.05 & 0.70 & 2.31 & 0.71 & 2.19 & 0.71 & $\mathrm{D}$ \\
\hline 3 & Husbands/wives do not support family planning & 2.05 & 0.66 & 2.26 & 0.61 & 2.16 & 0.64 & $\mathrm{D}$ \\
\hline 4 & My religion forbids birth control & 2.03 & 0.76 & 2.15 & 0.67 & 2.09 & 0.72 & $\mathrm{D}$ \\
\hline 5 & Lack of sex education at an early stage of life & 1.88 & 0.74 & 2.04 & 0.65 & 1.96 & 0.70 & $\mathrm{D}$ \\
\hline 6 & Too much waiting at the clinic & 1.93 & 0.63 & 2.20 & 0.64 & 2.08 & 0.65 & $\mathrm{D}$ \\
\hline 7 & Transportation problem to the clinic & 2.06 & 0.67 & 1.96 & 0.76 & 2.00 & 0.72 & $\mathrm{D}$ \\
\hline 8 & The high cost of contraceptives & 1.88 & 0.65 & 2.13 & 0.50 & 2.01 & 0.59 & $\mathrm{D}$ \\
\hline 9 & Few family planning agencies & 3.22 & 0.41 & 3.03 & 0.17 & 3.12 & 0.32 & A \\
\hline \multirow[t]{2}{*}{10} & To get expensive gifts from the husband when given to bed. & 2.03 & 0.72 & 2.20 & 0.55 & 2.12 & 0.64 & $\mathrm{D}$ \\
\hline & Cluster Mean & 2.14 & 0.26 & 2.25 & 0.25 & 2.19 & 0.26 & $\mathbf{D}$ \\
\hline
\end{tabular}

The results of the study as presented in Table 5 show the mean ratings and standard deviations of the problems in the use of birth control methods for family planning by male and female respondents in Nsukka Education Zone. The result of the study showed that both male and female respondents disagreed on all the items except item 9 . This is because the mean ratings for the items are below 2.50 set as a criterion for accepting an item. These mean that the respondents disagreed on the following as problems in the use of birth control methods for family planning. These include; fear of side effects, husbands/wives do not support family planning, religion forbids birth control, lack of sex education at an early stage of life, too much waiting at the clinic, transportation problem to the clinic and high cost of contraceptives among others. However, the respondents agreed that few family planning agencies is a problem in the use of birth control methods for family planning. The overall cluster mean of 2.19 with a standard deviation of 0.26 shows that the respondents disagreed on items in Table 5 as problems in the use of birth control methods for family planning.

\subsection{Hypothesis Three}

There is no significant difference in the mean responses of male and female married people on the problems in the use of birth control methods for family planning in Nsukka Education Zone.

Table 6.T-test analysis of the difference in the mean responses of male and female married people on the problems in the use of birth control methods for family planning

\begin{tabular}{|c|c|c|c|c|c|c|c|c|c|}
\hline \multirow{2}{*}{$\mathbf{S} / \mathbf{N}$} & \multirow{2}{*}{ Problems in the use of Birth Control Methods } & \multicolumn{2}{|c|}{ Male } & \multicolumn{2}{|c|}{ Female } & \multirow{2}{*}{ t-cal } & \multirow{2}{*}{ df } & \multirow{2}{*}{ Sig } & \multirow{2}{*}{ Dec } \\
\hline & & $\overline{\boldsymbol{X}}$ & SD & $\overline{\boldsymbol{X}}$ & SD & & & & \\
\hline 1 & $\begin{array}{l}\text { Only-child syndrome/I am the only child, therefore, I will } \\
\text { give birth as long as pregnancies come }\end{array}$ & 2.28 & 0.64 & 2.23 & 0.58 & 0.72 & 443 & 0.46 & NS \\
\hline 2 & Fear of side effects & 2.05 & 0.70 & 2.31 & 0.71 & -3.77 & 443 & 0.00 & $\mathrm{~S}$ \\
\hline 3 & Husbands/wives do not support family planning & 2.05 & 0.66 & 2.26 & 0.61 & -3.49 & 443 & 0.00 & S \\
\hline 4 & My religion forbids birth control & 2.03 & 0.76 & 2.15 & 0.67 & -1.76 & 443 & 0.07 & NS \\
\hline 5 & Lack of sex education at an early stage of life & 1.88 & 0.74 & 2.04 & 0.65 & -2.51 & 443 & 0.01 & $\mathrm{~S}$ \\
\hline 6 & Too much waiting at the clinic & 1.93 & 0.63 & 2.20 & 0.64 & -4.46 & 443 & 0.00 & $\mathrm{~S}$ \\
\hline 7 & Transportation problem to the clinic & 2.06 & 0.67 & 1.96 & 0.76 & 1.44 & 443 & 0.14 & NS \\
\hline 8 & The high cost of contraceptives & 1.88 & 0.65 & 2.13 & 0.50 & -4.56 & 443 & 0.00 & $\mathrm{~S}$ \\
\hline 9 & Few family planning agencies & 3.22 & 0.41 & 3.03 & 0.17 & 6.41 & 443 & 0.00 & $\mathrm{~S}$ \\
\hline \multirow[t]{2}{*}{10} & To get expensive gifts from the husband when given to bed. & 2.03 & 0.72 & 2.20 & 0.55 & -2.74 & 443 & 0.00 & $\mathrm{~S}$ \\
\hline & Cluster $\mathbf{t}$ & 2.14 & 0.26 & 2.25 & 0.25 & -4.51 & 443 & $\mathbf{0 . 0 0}$ & $\mathbf{S}$ \\
\hline
\end{tabular}


The result of the study as presented in Table 6 shows the t-test analysis of the significant difference in the mean responses of male and female married people on the problems in the use of birth control methods for family planning in Nsukka Education Zone. The result shows that the cluster t-value of -4.51 with a degree of freedom of 443 and significant value of 0.00 was obtained. Since the significant value of 0.00 is less than 0.05 set as a level of significance, this means the result is significant. The null hypothesis which stated that there is no significant difference in the mean responses of male and female married people on the problems in the use of birth control methods for family planning in Nsukka Education Zone is rejected. An inference drawn therefore is that there was a significant difference in the mean responses of male and female married people on the problems in the use of birth control methods for family planning in Nsukka Education Zone with the female respondents having a higher mean rating.

\subsection{Research Question Four}

What measures can be adopted to enhance family planning among male and female married people in Nsukka Education Zone?

Table 7. Mean ratings and standard deviation of respondents on the measures that can be adopted to enhance family planning

\begin{tabular}{|c|c|c|c|c|c|c|c|c|}
\hline \multirow[t]{2}{*}{$\mathbf{S} / \mathbf{N}$} & \multirow[t]{2}{*}{ Problems in the use of birth control methods } & \multicolumn{2}{|c|}{$\begin{array}{l}\text { Male } \\
\mathrm{N}=\mathbf{2 1 0}\end{array}$} & \multicolumn{2}{|c|}{$\begin{array}{l}\text { Female } \\
\mathbf{N}=\mathbf{2 3 5}\end{array}$} & \multicolumn{2}{|c|}{$\begin{array}{l}\text { Overall } \\
N=445\end{array}$} & \multirow[t]{2}{*}{ Dec. } \\
\hline & & $\bar{X}$ & SD & $\bar{X}$ & SD & $\bar{X}$ & SD & \\
\hline 1 & $\begin{array}{l}\text { Involving communities and community leaders on the need for family } \\
\text { planning }\end{array}$ & 3.27 & 0.68 & 3.63 & 0.56 & 3.46 & 0.64 & A \\
\hline 2 & Men should be allowed to take family planning decision & 3.21 & 0.63 & 3.63 & 0.52 & 3.44 & 0.61 & A \\
\hline 3 & Improved communication on sustained contraceptive use & 3.00 & 0.66 & 3.37 & 0.54 & 3.19 & 0.63 & A \\
\hline 4 & $\begin{array}{l}\text { Disseminating birth control messages through mass media/family planning } \\
\text { campaign through mass media }\end{array}$ & 3.02 & 0.64 & 3.46 & 0.58 & 3.25 & 0.65 & A \\
\hline 5 & $\begin{array}{l}\text { Making family planning facilities available and accessible to the general } \\
\text { public }\end{array}$ & 3.20 & 0.40 & 3.20 & 0.40 & 3.20 & 0.40 & A \\
\hline 6 & Proper education on birth control and family planning & 2.94 & 0.62 & 3.39 & 0.57 & 3.18 & 0.64 & A \\
\hline 7 & Formation of "fathers and mothers forum" in maternity homes & 3.01 & 0.70 & 3.51 & 0.59 & 3.28 & 0.69 & A \\
\hline 8 & Pills and condoms should be given free to married couples & 2.99 & 0.73 & 3.40 & 0.57 & 3.21 & 0.68 & A \\
\hline 9 & $\begin{array}{l}\text { Evidence-based information on effectiveness, risks and benefits of } \\
\text { different methods }\end{array}$ & 2.96 & 0.73 & 3.57 & 0.58 & 3.28 & 0.72 & A \\
\hline \multirow[t]{2}{*}{10} & Government to include birth control and family planning in the budget & 2.95 & 0.71 & 3.60 & 0.57 & 3.29 & 0.72 & A \\
\hline & Cluster Mean & 3.05 & 0.28 & 3.47 & 0.20 & 3.27 & $\mathbf{0 . 3 2}$ & $\mathbf{A}$ \\
\hline
\end{tabular}

The results of the study as presented in Table 7 show the mean ratings and standard deviations of the of respondents on the measures that can be adopted to enhance family planning among male and female married people in Nsukka Education Zone. The result of the study showed that both male and female respondents agreed on all the items in Table 7 as measures to enhance family planning. This is because the mean ratings for the items are above2.50 set as a criterion for accepting an item. These imply that the following are measures that can be adopted to enhance family planning among male and female married people in Nsukka Education Zone. These include; involving communities and community leaders on the need for family planning, men should be allowed to take family planning decision, improved communication on sustained contraceptive use, disseminating birth control messages through mass media/family planning campaign through mass media, making family planning facilities available and accessible to the general public, proper education on birth control and family planning and formation of "fathers and mothers forum" in maternity homes among others. The overall cluster mean of 3.27 with a standard deviation of 0.32 shows that the respondents agreed on items in Table 7 as measures that can be adopted to enhance family planning among male and female married people in Nsukka Education Zone. 


\subsection{Hypothesis Four}

There will be no significant difference in the mean responses of male and female married people on measures that can be adopted to enhance family planning among married people in Nsukka Education Zone?

Table 8. T-test analysis of the difference in the mean responses of male and female married people on the measures that can be adopted to enhance family planning

\begin{tabular}{|c|c|c|c|c|c|c|c|c|c|}
\hline \multirow{2}{*}{$\mathrm{S} / \mathrm{N}$} & \multirow{2}{*}{$\begin{array}{l}\text { Measures that can be adopted to Enhance Family } \\
\text { Planning }\end{array}$} & \multicolumn{2}{|c|}{ Male } & \multicolumn{2}{|c|}{ Female } & \multirow[t]{2}{*}{ t-cal } & \multirow[t]{2}{*}{ df } & \multirow[t]{2}{*}{ Sig } & \multirow[t]{2}{*}{ Dec } \\
\hline & & $\overline{\bar{X}}$ & SD & $\overline{\bar{X}}$ & SD & & & & \\
\hline 1 & $\begin{array}{l}\text { Involving communities and community leaders on the need } \\
\text { for family planning }\end{array}$ & 3.27 & 0.68 & 3.63 & 0.56 & -6.12 & 443 & 0.00 & $\mathrm{~S}$ \\
\hline 2 & Men should be allowed to take family planning decision & 3.21 & 0.63 & 3.63 & 0.52 & -7.59 & 443 & 0.00 & $\mathrm{~S}$ \\
\hline 3 & Improved communication on sustained contraceptive use & 3.00 & 0.66 & 3.37 & 0.54 & -6.36 & 443 & 0.00 & $\mathrm{~S}$ \\
\hline 4 & $\begin{array}{l}\text { Disseminating birth control messages through mass } \\
\text { media/family planning campaign through mass media }\end{array}$ & 3.02 & 0.64 & 3.46 & 0.58 & -7.46 & 443 & 0.00 & $\mathrm{~S}$ \\
\hline 5 & $\begin{array}{l}\text { Making family planning facilities available and accessible } \\
\text { to the general public }\end{array}$ & 3.20 & 0.40 & 3.20 & 0.40 & 0.01 & 443 & 0.98 & NS \\
\hline 6 & Proper education on birth control and family planning & 2.94 & 0.62 & 3.39 & 0.57 & -7.94 & 443 & 0.00 & $\mathrm{~S}$ \\
\hline 7 & $\begin{array}{l}\text { Formation of "fathers and mothers forum" in maternity } \\
\text { homes }\end{array}$ & 3.01 & 0.70 & 3.51 & 0.59 & -8.10 & 443 & 0.00 & $\mathrm{~S}$ \\
\hline 8 & Pills and condoms should be given free to married couples & 2.99 & 0.73 & 3.40 & 0.57 & -6.54 & 443 & 0.00 & $\mathrm{~S}$ \\
\hline 9 & $\begin{array}{l}\text { Evidence-based information on effectiveness, risks and } \\
\text { benefits of different methods }\end{array}$ & 2.96 & 0.73 & 3.57 & 0.58 & -9.67 & 443 & 0.00 & $\mathrm{~S}$ \\
\hline \multirow[t]{2}{*}{10} & $\begin{array}{l}\text { Government to include birth control and family planning in } \\
\text { the budget }\end{array}$ & 2.95 & 0.71 & 3.60 & 0.57 & -10.58 & 443 & 0.00 & $\mathrm{~S}$ \\
\hline & Cluster t & 3.05 & 0.28 & 3.47 & 0.20 & -17.94 & 443 & 0.00 & $\mathbf{S}$ \\
\hline
\end{tabular}

The result of the study as presented in Table 8 shows the t-test analysis of the significant difference in the mean responses of male and female married people on measures that can be adopted to enhance family planning among married people in Nsukka Education Zone. The result shows that the cluster t-value of -17.94 with a degree of freedom of 443 and significant value of 0.00 was obtained. Since the significant value of 0.00 is less than 0.05 set as a level of significance, this means the result is significant. The null hypothesis which stated that there is no significant difference in the mean responses of male and female married people on measures that can be adopted to enhance family planning among married people in Nsukka Education Zone is rejected. An inference drawn therefore is that there was a significant difference in the mean responses of male and female married people on measures that can be adopted to enhance family planning among married people in Nsukka Education Zone.

\subsection{Knowledge of Common Birth Control Methods of Family Planning by Married Male and Female People}

The findings of the study revealed that the respondents (both male and female) have knowledge of common birth control methods of family planning in Nsukka Education Zone. The result also revealed that there was a significant difference in the mean responses of males and females on knowledge of common birth control methods of family planning in Nsukka Education Zone with the female respondents having a higher mean rating than their male counterparts. Most of the participants had knowledge of at least one contraceptive method with condom being the most commonly known method. This finding supports the finding of Omolase, Faturoti and Omolase (2009) who found that a higher number of married females know about family planning. The finding is also in line with Aziken, Okonta, Adedapo's (2003) finding that the majority of men and women are aware of contraceptives. However, the results do not support Oye-Adeniran, Adeqole, Odeyemi, Ekanem and Umoh, (2005) who posited that men do not support the issue of birth control.

\subsection{The Extent of Birth Control Methods by Male and Female Married People in Nsukka Education Zone}

The study found that both male and female make use of birth control methods for family planning in NsukkaEducation Zone to a great extent. The study also revealed that there was a significant difference in the mean 
responses of male and female married people on the extent to which married people make use of birth control methods of family planning in Nsukka Education Zone. The finding is in line with that of Akafuah and Sossou (2008) who found that men are willing to use a family planning method. The finding is also in consonance with the findings of Ifeadike, Eze, Ugwoke and Nnaji (2015) who found that more married men than women use family planning method with condom being the commonest method.

\subsection{The Problems in the use of Birth Control Methods of Family Planning by Male and Female Married People in Nsukka Education Zone}

The result of the study showed that both male and female respondents disagreed on the following as problems in the use of birth control methods for family planning.; fear of side effects, husbands/wives do not support family planning, religion forbids birth control, lack of sex education at an early stage of life, too much waiting at the clinic, transportation problem to the clinic and high cost of contraceptives among others. However, the respondents agreed that few family planning agencies is a problem in the use of birth control methods for family planning. It was further revealed that there was a significant difference in the mean responses of male and female married people on the problems in the use of birth control methods for family planning in Nsukka Education Zone with the female respondents having a higher mean rating.These findings do not support Akingba (2006) who pointed out that many Nigerian males' couples do not approve birth control/contraceptives for their wives because they fear that birth control application will make their wives become harlots. The finding is not in line with Fan and Edinyang's (2007), assertion that religion is another factor that hinders birth control. Also, the finding was not in agreement with Iffih and Ezeah (2004) who posited that forbidding the young ones from having the slightest idea of sex and its related aspects makes them grow into adulthood quite educated but have no knowledge of birth control.

\subsection{The Measures to be Adopted to Enhance Family Planning by Male and Female Married People in Nsukka Education Zone}

The result of the study showed that the respondents agreed on the following; involving communities and community leaders on the need for family planning, men should be allowed to take family planning decision, improved communication on sustained contraceptive use, disseminating birth control messages through mass media/family planning campaign through mass media, making family planning facilities available and accessible to the general public, proper education on birth control and family planning and formation of "fathers and mothers forum" in maternity homes among others as measures that can be adopted to enhance family planning among male and female married people in Nsukka Education Zone. Again, the result confirmed that there was a significant difference in the mean responses of male and female married people on measures that can be adopted to enhance family planning among married people in Nsukka Education Zone. The study supports Ajaero, Odimegwu, Ajaero and Nwachukwu (2016) who found that one of the strategies often employed in the promotion of family planning is the utilization of mass media. It is also in line with Cheng (2011) who established that mass media and social networks played important roles in disseminating contraceptive knowledge and that women transformed this knowledge into behaviour that is contraceptive knowledge reduced fertility. Furthermore, the study supports Ademola et al (2014) who stated that spousal communication has a strong positive effect on sustained contraceptive use. The study also supports Eze and Adhune (2014) assertion that for family planning to improve, the government should form a "fathers forum" in maternity homes where they will be taught the importance of family planning and improve the material of child health, better spacing and better control and training of the already born children. Also, the study is in agreement with Ajaero, Odimegwu, Ajaero and Nwachukwu (2016) who posited that one of the strategies often employed in the promotion of family planning is the utilization of mass media to make populations aware of the benefits of the use of family planning. The findings also supported the existing community structure and community leaders should be used to inform people about family planning and make services and supplies accessible such as through community-based distribution and social marketing. The results also support Eze and Adhune's (2014) assertion that for family planning to improve, government should form a "fathers forum" in maternity homes where they will be taught the importance of family planning and improve material of child health, better spacing and better control and training of the already born children, that schools should organize and educate parent during the Parents Teachers Association (PTA) meetings using drama and songs and that married couples should be helped via enlightenment programmes such as symposium and seminars.

\section{Conclusion}

Based on the data presented and analyzed it was discovered that married people have knowledge of birth control methods for family planning with married females having more knowledge than married males. The result also 
established that both males and females married people make use of birth control methods of family planning with condom being the most common method for males. It was also established that a few family planning agencies cause problem in the use of birth control methods for family planning. The following; involving communities and community leaders on the need of family planning, allowing men to take family planning decision, improved communication on sustained contraceptive use and disseminating birth control messages through mass media/family planning campaign were established as measures that can be adopted to enhance family planning among male and female married people. Again, making family planning facilities available and accessible to the general public, proper education on birth control and family planning and formation of "fathers and mothers forum" in maternity homes among others were also established as measures that can be adopted to enhance family planning among male and female married people. There was a significant difference in the mean response of male and female married people on the knowledge of common birth control methods, the extent to which married people make use of birth control methods, problems in the use of birth control methods, and on measures that can be adopted to enhance family planning among married people. Thus, based on this conclusion, the implications, recommendations and suggestions for further study where therefore drawn in this study.

\subsection{Implications of the Study}

The findings that both male and female married people have knowledge of common birth control methods of family planning implies that couples should discuss together which birth control method of family planning they want to adopt. It should not be a one-man affair.

The findings that there is a significant difference in the mean response of males and females on knowledge of common birth control methods of family planning with the female respondents having a higher mean rating than their male counterparts implies that the female spouse can initiate the discussion on family planning if she is more knowledgeable about it.

The findings that there was a significant difference in the mean responses of male and female married people on measures that can be adopted to enhance family planning implies that couples should agree on the particular birth control method they want to use.

Another implication of the study is that men should be involved in healthcare programs designed to improve acceptance of family planning as they mostly influence decision-making at the household level and this will also result in active male participation at the community level.

\subsection{Recommendations}

- This study recommended that the male population be fully integrated into the family planning programmes.

- $\quad$ sensitization programmes aimed at improving male involvement in family planning should be provided by the government and non-governmental agencies

- Men should be provided with information and this will make them to be more supportive of contraceptive use and more aware of the concept of shared decision-making.

\section{Competing Interests Statement}

The authors declare that there are no competing or potential conflicts of interest.

\section{References}

Agbe, N. N. (1998). The efficacy of counseling for mental adjustment. The Counselor, 16(1), 147-155.

Ajaero, C. K., Odimegwu, C., Ajaero, I. D., \& Nwachukwu, C. A. (2016).Access to mass media messages and use of family planning in Nigeria.A spatio-demographic analysis. BMC Public Heath, 16, 427. https://doi.org/10.1186/s12889-016-2979-z

Anyanwu, J. I., \& Ofordile, C. (2012).Marriage \& Family: Issues, problem and counseling strategies. Enugu: Snaap Press Ltd.

Anyanwu, K. A., \& Kanu, C. M. (2006). Distress in marriage and family life: Implication for guidance and counseling. The Journal of Counselling Association of Nigeria, 22(4), 56-89.

Bankole, A., Rodriguez, G., \& Westoff, C. F. (1996). Mass media messages and reproductive behaviour in Nigeria. Journal of Biosocial Science, 28(2), 227-239.https://doi.org/10.1017/S0021932000022264

Beguy, D., Bocquier, P., \& Zulu, E. M. (2010). Circular migration patterns and determinants in Nairobi slum settlements. Demographic Research, 23, 549-586. https://doi.org/10.4054/DemRes.2010.23.20 
Bryan, S., Christine, D., Barbara, W. S., \& William, L. Y. (2005). Human sexuality: Diversity in contemporary America (5th ed.). New York: McGraw Hill.

Coleman, S. (1992). Family planning in Japanese society: Traditional birth control in a modern urban culture. Princeton University Press.

Eze, B. U., \&Adhure, H. (2014).Hindrances to effective usage of family planning methods among women in AdomokoloLokoja urban area of Kogi State, Nigeria. International Journal of Current Research and Academic Review, 2(11), 234 -3215.

Eze, B. U., \& Okeke, B. A. (2014). Adoption of family planning measures among couples in new haven Enugu State, Nigeria. International Journal of Current Microbiology and Applied Sciences, 3(11), 454-463.

Eke, G. K., Ofori, P. I., \& Tabansi, P. N. (2011). Perception of rape amongst secondary school students in Port Harcourt. Nigerian Health Journal, 11(1), 23-26.

Eze, B.U., \& Okeke, B. A. (2014). Adoption of family planning measures among couples in new haven Enugu State, Nigeria. International Journal of Current Microbiology and Applied Sciences, 3(11), 454-463.

Ezugw, A., \& Omeje, P. (2010). Problems of family planning in Ibagwa-Aka L.G.A of Enugu State (Unpublished M.Ed Project, University of Nigeria, Nsukka).

Evans, E., Patel, M., \& Stranton, D. (2007).Student pharmacist knowledge and attitudes regarding oral emergency contraception. Journal of the American Pharmacists Association, 47(6), 711-719a. https://doi.org/10.1331/JAPhA.2007.06143

Fan, F. A., Usoro, S. U., \& Edinyang, S. D. (2007).Towards the enhancement of population and family life education for Nigerians.

Giami, A. (2002). Sexual health: the emergence, development, and diversity of a concept. Annual Review of Sex Research, 13(1), 1-35.

Hofman, P. L., Regan, F., Jackson, W. E., Jefferies, C., Knight, D. B., Robinson, E. M., \& Cutfield, W. S. (2004). Premature birth and later insulin resistance. New England Journal of Medicine, 351(21), 2179-2186. https://doi.org/10.1056/NEJMoa042275

Hurcom, C., Copello, A., \& Orford, J. (2000). The family and alcohol: Effects of excessive drinking and conceptualizations of spouses over recent decades. Substance Use \& Misuse, 35(4), 473-502. https://doi.org/10.3109/10826080009147469

Iffih, B. N., \& Ezeah, P. C. (2004). Sociology of family. Enugu: John Jacob's Classic Publishers Ltd.

Ikechebelu, J. I., Ikechebelu, N. N., \& Obiaulu, F. N. (2005). Knowledge, attitude and practice of family planning among Igbo women of south-eastern Nigeria. Journal of Obstetrics and Gynecology, 25(8), 792 -795. https://doi.org/10.1080/01443610500328231

Mcsweeney, I. (2011). Love and life: Billings method of family planning. Lagos: African University Press.

Ndom, R. J., Igbokwe, D. O., \& Ekeruo, N. (2012). Students'opinion on Substance Use, Violent Behavior and Possible Intervention Strategies in a Nigerian Public University. European Scientific Journal, 8(19).

Ngwu, C. N. (2014). Awareness and attitudes of family planning among rural women of Nsukka local government are: Implication for social work intervention. Mediterranean Journal of Social Sciences, 5(27), 590-598.

Nwachukwu, I., \& Obasi, O. O. (2008). Use of modern birth control methods among rural communities in Imo State, Nigeria. African Journal of Reproductive Health, 12(1), 101-108.

Nworgu, B. G. (2015). Educational research: basic issues and methodology (3rd ed.). Nsukka: University Trust Publishers.

Nwosu, E. N., \& Omeje, J. C. (2008). Gender Differences in Communication Patterns of Females in Single-Sex and Mixed-Sex Schools in Nnewi Education Zone. African Research Review, 2(3), 103-115. https://doi.org/10.4314/afrrev.v2i3.41062

Ogbe, C. O. A., \& Okezie, C. R. (2010).Socio-economic determinants of contraceptive use among rural women in Ikwuano Local Government Area of Abia State, Nigeria. International NGO Journal, 5(4), 74-77.

Okere, A. U., \& Onyechi, K. C. (2010). Knowledge and use of birth control and contraception methods by married people in Enugu state, Nigeria for family planning. A paper presented at the 38th annual conference of the counselling association of Nigeria (Acason) At NnamdiAzikiwe Stadium Enugu 2nd Aug-7th August, 2010. 
Olaitan, O. L. (2011). Factors influencing the choice of family planning among couples in south west Nigeria. International Journal of Medical Science, 3(7), 227-322.

Olaitan, O. L. (2009). Sexual behavior of university students in south west Nigeria. Egypt Acad Journal Biological Science (Zool), 1(1), 85-93.https://doi.org/10.21608/eajbsz.2009.16024

Olugbenga-Bello, A. I., Abodunrin, O. L., \&Adeomi, A. A. (2011). Contraceptive practices among women in rural communities in south-western Nigeria. Global Journal of Medical Research, 11(2).

Omolase, C. O., Faturoti, S. O., \& Omolase, B. O. (2009). Awareness of family planning amongst antenatal patients in Nigeria community: an exploratory study. Annuals of Ibadan Postgraduate Medicine, 7(1), 50-85. https://doi.org/10.4314/aipm.v7i1.64076

Onyima, B. N. (2014). Marriage ceremony: the clash between traditional marriage rites and western marriage. Journal of Religion and Human Relations, 1(6), 171-180.

Planned Parenthood Federation of America. (2006). A history of birth control methods. New York: Katherine Dexter, Mccormick Library.

Rathi, Y. S. (2006). Study of Technological Gap In Farming Systems In District Baghpat UP.

Reynolds, M. R., Jones, A. M., Petersen, E. E., Lee, E. H., Rice, M. E., Bingham, A., ... \& Brown, C. M. (2017). Vital signs: update on Zika virus-associated birth defects and evaluation of all US infants with congenital Zika virus exposure-US Zika Pregnancy Registry, 2016. MMWR.Morbidity and Mortality Weekly Report, 66(13), 366. https://doi.org/10.15585/mmwr.mm6613e1

Schneider, D. T., Calaminus, G., Koch, S., Teske, C., Schmidt, P., Haas, R. J., ... \& Göbel, U. (2004). Epidemiologic analysis of 1,442 children and adolescents registered in the German germ cell tumor protocols. Pediatric blood \& cancer, 42(2), 169-175.https://doi.org/10.1002/pbc.10321

Tahir, M. Z. (2019). Education, Electronic Media and Family Planning: Pakistan Demographic and Health Survey 2012-13. Journal of Saidu Medical College, 9(1).

Udigwe, G. O., Udigwe, R. I., \& Ikechebelu, J. I. (2002). Contraceptive practice in a teaching hospital in South-east, Nigeria. Journal of Obstetrics Gynecology, 22(2), 308-311. https://doi.org/10.1080/01443610220130652

Undelikwo, V. A., Osonwa, O. K., Ushie, M. A., \& Osonwa, R. H. (2013). Family planning behaviours and decision-making among couples in Cross River State, Nigeria. International Journal of Learning and Development, 3(1). https://doi.org/10.5296/ijld.v3i1.3146

United Nations. (2005). World population prospect: The 2004 revision. New York: United Nations.

Williams, B. K., Sawyer, S. C., \& Wahlstrom, C. (2012). Marriages, families, and intimate relationships. Pearson Education.

World Health Organization. (2015). What do we mean by "sex" and gender. Retrieved November, 2015 from who.int/sex/gender topics/spr-3/en/

\section{Copyrights}

Copyright for this article is retained by the author(s), with first publication rights granted to the journal.

This is an open-access article distributed under the terms and conditions of the Creative Commons Attribution license (http://creativecommons.org/licenses/by/4.0/). 